\title{
Pulsatilla patens i P. pratensis (Ranunculaceae) na czynnych poligonach wojskowych w południowo-wschodniej Polsce - liczebność, struktura rozmieszczenia i ochrona
}

\author{
ADAM RAPA i RAFAE KRAWCZYK
}

\begin{abstract}
Rapa, A. AND KrawCZYK, R. 2020. Pulsatilla patens and P. pratensis (Ranunculaceae) in active military training areas of south-eastern Poland - population size, distribution pattern and conservation. Fragmenta Floristica et Geobotanica Polonica 27(2): 509-526. Kraków. e-ISSN 2449-8890, ISSN 1640-629X.
\end{abstract}

\begin{abstract}
In a population study of the endangered species Pulsatilla patens and $P$. pratensis conducted between 2010 and 2019 in two active military training areas (Nowa Dęba, Lipa), we found that the pasque flower metapopulations consisted of widely dispersed small clusters or single individuals. They inhabited psammophilous grassland, dry heath, forest edges and initial pine forest. In Lipa we found 34 clumps of $P$. patens and 9 clumps of $P$. pratensis, and in Nowa Dęba 2 and 25 clumps, respectively. The share of generative plants in the study period ranged from 0.19 to 0.56 for $P$. patens and from 0.44 to 0.52 for $P$. pratensis. Based on detailed monitoring of $P$. patens at seven sites, we determined that the number of individuals had gradually decreased, resulting in reduction of the population by almost half over the decade. At the same time we observed a pronounced fluctuation in the number of generative clumps and flowering shoots. Neither seedlings nor juvenile plants of $P$. patens were found during the study period.
\end{abstract}

KEY WORDS: distribution pattern, endangered species, military training areas, population dynamics, Pulsatilla patens, Pulsatilla pratensis, relict population

A. Rapa, Potok Stany 123, 23-313 PotokWielki,Polska; e-mail: adamrapa78@wp.pl

R. Krawczyk, Katedra Zoologii i Ochrony Przyrody, Instytut Nauk Biologicznych, Uniwersytet Marii Curie-Skłodowskiej, ul. Akademicka 19, 20-033 Lublin, Polska; e-mail: rafal.krawczyk@ umcs.lublin.pl

\section{WSTĘ}

Gatunki z rodzaju Pulsatilla Mill. należą do wymierających elementów flory zarówno w Polsce, jak i w innych krajach europejskich (KAŹMIERCZAKOwA i in. 2014, 2016). Do głównych przyczyn ich recesji zalicza się: zanik dogodnych siedlisk spowodowany zmianami w sposobie użytkowania, pozyskiwanie roślin ze stanu dzikiego ze względu na duże walory estetyczne kwiatów oraz zmiany klimatyczne (ZYCH 2007). Negatywne oddziaływanie dwóch pierwszych czynników jest znacznie ograniczone na czynnych poligonach wojskowych, co daje możliwość obserwacji lokalnych populacji w warunkach odmiennych od tych, które panują we współczesnym krajobrazie. Poligony użytkowane są w sposób dosyć chaotyczny, ich ekosystemy podlegają licznym zaburzeniom, zarówno mechanicznym, jak 
i częstym pożarom, czego efektem jest heterogeniczny krajobraz, którego roślinność reprezentuje różne stadia sukcesji, w tym również pionierskie. Ponadto obszary poligonowe nie są narażone na silną eutrofizację i penetrację przez człowieka. Specyficzne uwarunkowania sprawiają, że poligony funkcjonują jako wyspy siedliskowe, a w ich granicach znaleźć można duże zasoby ustępujących typów zbiorowisk oraz silnie zagrożone gatunki, których populacje mają czasami charakter reliktowy.

Wyspowy lub nawet reliktowy charakter, zawężony do czynnych poligonów, mają potwierdzone w ostatnich latach populacje Pulsatilla patens (L.) Mill. (sasanki otwartej) i Pulsatilla pratensis (L.) Mill. (sasanki łąkowej) w południowo-wschodniej Polsce. Poligony wojskowe są jedynymi stanowiskami obydwu gatunków, jakie stwierdzono w ostatnim czasie na terenie województwa podkarpackiego (OKLEJEwICz i in. 2015). Na szczególną uwagę zasługuje ten pierwszy, który w szybkim tempie ustępuje z obszaru Polski i jest jednocześnie gatunkiem specjalnej troski w granicach całej Unii Europejskiej (DYREKTYwA 1992). Jego stanowiska w południowo-wschodniej Polsce leżą na granicy ogólnego zasięgu.

Dzięki licznym badaniom oraz wiedzy uzyskanej w trakcie monitoringu przyrodniczego, sasanka otwarta jest obecnie gatunkiem o stosunkowo dobrze poznanym rozmieszczeniu, zasobach i ekologii (ZYCH 2007; PAWLIKOWSKi 2012; PAWLIKOWSKI \& WóJTOWICZ 2014).

Mniej miejsca w literaturze poświęca się sasance łąkowej. Pewną luką w wiedzy jest też brak danych o strukturze rozmieszczenia osobników w lokalnych populacjach. W badaniach, które dotyczą zwykle niewielkich izolowanych populacji lub subpopulacji, rzadko przedstawia się szczegółowe informacje o relacjach przestrzennych pomiędzy badanymi osobnikami, a co za tym idzie nie jest jasne, czy takie zgrupowania osobników pozostają względem siebie w izolacji.

Celem badań było zgromadzenie wiedzy z zakresu ekologii sasanek Pulsatilla patens i $P$. pratensis, występujących na terenie czynnych poligonów wojskowych. Cele szczegółowe można określić następująco: określenie liczebności oraz struktury przestrzennej populacji badanych gatunków, określenie wieloletniej dynamiki liczebności $P$. patens, zebranie danych dotyczących charakteru zajmowanych siedlisk oraz określenie czynników zagrażających badanym populacjom.

\section{CHARAKTERYSTYKA BADANYCH GATUNKÓW}

Obydwa gatunki to hemikryptofity i długowieczne byliny. Rozgałęziony organ podziemny zakończony jest skróconymi pędami, które wytwarzają rozety liściowe, starsze osobniki, złożone z kilku do kilkunastu rozet, formują wyraźne kępy. Pędy kwiatowe zakończone są pojedynczym kwiatem zapylanym przez owady. Autogamia jest potencjalnie możliwa, ale w warunkach naturalnych prawdopodobnie zachodzi bardzo rzadko (TORVIK i in. 1998). Owocem jest jednonasienna niełupka opatrzona aparatem lotnym, jednak o małej efektywności, co sprawia że większość owoców spada w pobliżu rośliny macierzystej, a niełupki zachowują żywotność przez kilka lat (WóJTOwicz 2000, 2004; PiLT \& KuKK 2002). W cyklu życiowym, który może przebiegać według różnych schematów, osobniki sasanek przechodzą przez kilka stadiów rozwojowych (KRICSFALUSY 2016). 
Pulsatilla patens i $P$. pratensis różnią się pod względem ogólnego rozmieszczenia, jakkolwiek ich zasięgi pokrywają się na terenie Europy Środkowej i Europy Wschodniej. Sasanka otwarta jest gatunkiem cyrkumborealnym (HULTÉN \& FRIES 1986); jej zasięg rozciąga się od $70^{\circ}$ długości geograficznej wschodniej po Europę Środkową. Na początku XX w. zasięg sasanki otwartej obejmował południową i zachodnią Polskę, sięgając okolic Szczecina i Brandenburgii w Niemczech (WóJTOwicz 2000; ZAJĄC \& ZAJąC 2001; PAWLIKOWSKI \& WósTOWICZ 2014). Obecna granica występowania tego gatunku przesunęła się w kierunku wschodnim i przebiega obecnie od Kotliny Sandomierskiej, przez Wyżynę Kielecką, Mazowsze, okolice Torunia do Borów Tucholskich. Sasanka łąkowa, w odróżnieniu od sasanki otwartej, ma mniejszy zasięg, który jest ograniczony do Europy. Gatunek ten występuje w południowej Szwecji, wschodniej Europie (od Estonii po Ukrainę), Polsce (część niżowa), Niemczech oraz Czechach i Austrii (Jalas \& SuOMinen 1989; ZAJąC \& ZAJĄC 2001).

Oba gatunki sasanek zajmują podobne siedliska występując czasami sympatrycznie. Sasanka otwarta zasiedla głównie bory sosnowe i mieszane Dicrano-Pinion, najbardziej typowym jej siedliskiem w Polsce jest kontynentalny bór sosnowy Peucedano-Pinetum (Ciosek 1999; Pilt \& Kukk 2002; Juśkiewicz-Swaczyna 2010; Czerepko i in. 2014; CioseK i in. 2016); gatunek ten notowany był także w świetlistej dąbrowie Potentillo albae-Quercetum (NoBIS \& NoBIs 2009). Na obszarach leśnych osobniki spotyka się najczęściej na skrajach lasów, wzdłuż dróg, nasypów kolejowych i linii działowych. Poza siedliskami leśnymi sasanka otwarta rośnie na suchych wrzosowiskach i w murawach napiaskowych (Juśkiewicz-Swaczyna \& GRZYBowski 2013; CzEREPKo i in. 2014), sporadycznie spotykana była w murawach kserotermicznych (CEYNOwA 1968; RÖDER \& KIEHL 2006).

Sasanka łąkowa, w porównaniu do sasanki otwartej, preferuje bardziej siedliska otwarte; występuje w obrębie suchych muraw, w tym muraw kserotermicznych, rzadziej w borach sosnowych (Ciosek 1999; Pilt \& KuKK 2002; KrZEPTOwSKa i in. 2006; GRZYL 2012).

Sasanka otwarta została w Polsce sklasyfikowana jako gatunek zagrożony EN (PAwLIKOWSKI \& WóJTOWICZ 2014; KAŹMIERCZAKOWA i in. 2016). W „czerwonej księdze” województwa podkarpackiego Pulsatilla patens ma status gatunku krytycznie zagrożonego CR (OKLEJEwICZ $\mathrm{i}$ in. 2015), natomiast $\mathrm{w}$ województwie lubelskim uważana jest za takson wymarły RE (CwENER i in. 2016). Kurczenie się zasięgu i postępujący spadek liczebności populacji w kraju notuje się od połowy XX w. Obecnie najwięcej stanowisk sasanki otwartej, w tym najbardziej zasobnych w osobniki, znajduje się w północno-wschodniej Polsce. W pozostałych regionach populacje $P$. patens stają się stopniowo mniej liczne, nawet skrajnie nieliczne, złożone z kilku osobników (PAWLIKOwsKi 2012; CzEREPKo i in. 2014). Pulsatilla pratensis posiada w Polsce niższą kategorię zagrożenia VU (KAźMIERCZAKOWA i in. 2016), chociaż w województwie podkarpackim ustalono, że gatunek jest silnie zagrożony CR (OKLEJEWICZ i in. 2015). Wszystkie gatunki sasanek podlegają w Polsce ochronie ścisłej (RozPORZĄDZENIE 2014). Sasanka otwarta jest również wpisana do załącznika II i IV Dyrektywy Siedliskowej, co oznacza że jej ochrona wymaga tworzenia specjalnych obszarów ochrony (DYREKTYWA 1992). 


\section{TEREN BADAŃ}

Teren badań obejmował dwa czynne poligony wojsk lądowych (Nowa Dęba i Lipa) zlokalizowane na piaszczystych, miejscami silnie zwydmionych, równinach (Równina Biłgorajska, Równina Tarnobrzeska) północnej części Kotliny Sandomierskiej (Ryc. 1). Obszar ten w znacznym stopniu pokryty jest lasami; dominują siedliska oligo- i mezotroficzne ze zbiorowiskami borowymi, przeważnie ze związku Dicrano-Pinion. Na ich tle badane poligony, a ściślej mówiąc ich pola robocze (place ćwiczeń), mają charakter dużych nieleśnych wysp. Obecnie jednak w wielu miejscach, szczególnie na poligonie lipskim, obserwuje się zaawansowane procesy sukcesyjne, w wyniku czego tworzy się mozaikowaty krajobraz złożony ze zbiorowisk otwartych, półotwartych oraz inicjalnych borów sosnowych. Miejsca otwarte poligonów zajmują głównie suche wrzosowiska (Pohlio-Callunion, Calluno-Arctostaphylion), które współwystępują z mniejszymi i rozproszonymi płatami muraw napiaskowych ze związku Corynephorion canescentis, rzadziej Koelerion glaucae, oraz okrajkami Trifolio-Geranietea.

Na chwilę obecną obydwa poligony wykorzystywane są do celów wojskowych. Poligon w Nowej Dębie jest częścią Ośrodka Szkolenia Poligonowego Wojsk Lądowych - Dęba (OSPWL-Dęba) i jest regularnie użytkowany od czasów II wojny światowej. Pole robocze tego poligonu to około 3000 ha. Poligon w Lipie w ostatniej dekadzie był użytkowany zarówno przez OSPWL w Nowej Dębie, jak i przez Wojskowy Instytut Techniczny

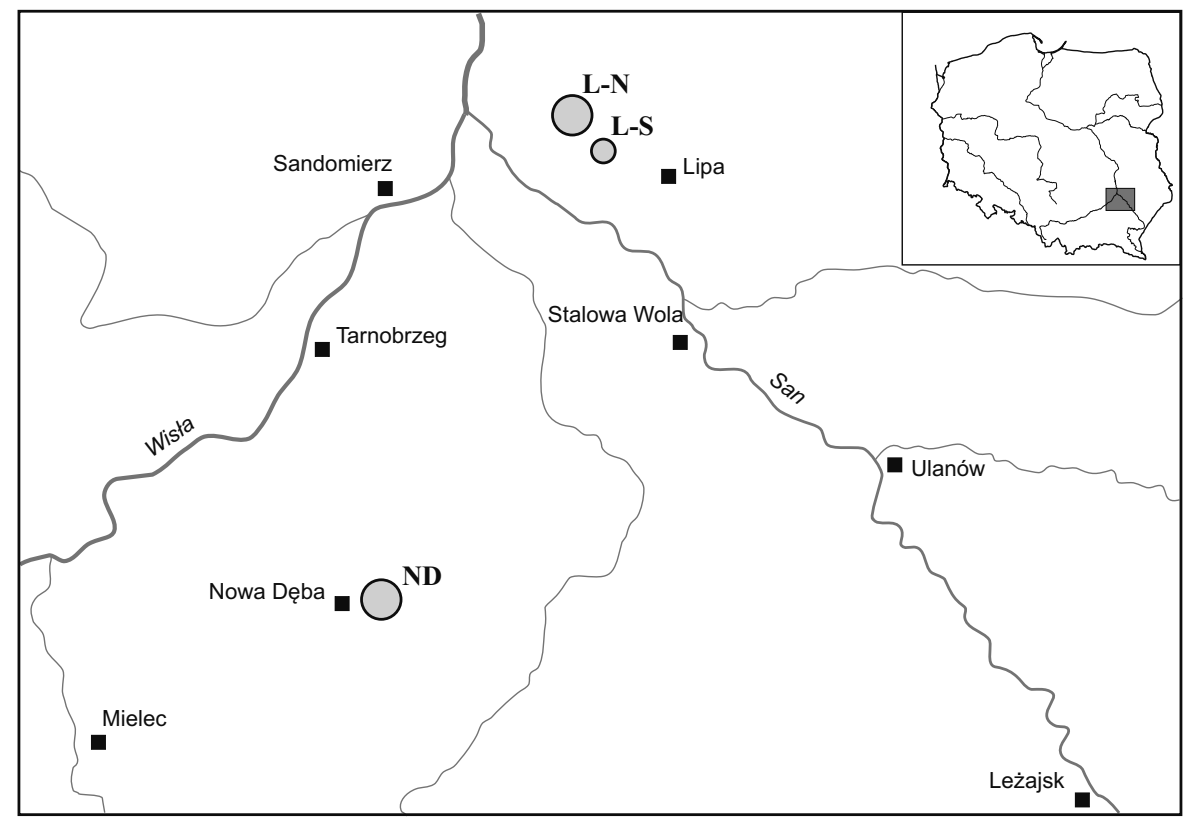

Ryc. 1. Położenie badanych poligonów wojskowych. L-N - Lipa część północna, L-S - Lipa część południowa, ND - Nowa Dęba

Fig. 1. Location of the study area. L-N - northern part of Lipa MTA, L-S - southern part of Lipa MTA, ND - Nowa Dęba MTA 
Uzbrojenia w Zielonce. W skład poligonu w Lipie wchodzą dwa pola robocze - duże na północy (1300 ha) i małe na południu (90 ha), oddalone od siebie o $2 \mathrm{~km}$.

Poligony wojskowe w Nowej Dębie i Lipie należą do obszarów o wysokich walorach przyrodniczych. Zarówno poligon w Lipie, jak i w Nowej Dębie wchodzą w skład siedliskowych obszarów Natura 2000 - PLH060031 Uroczyska Lasów Janowskich i PLH180055 Enklawy Puszczy Sandomierskiej (RogaŁA \& MARCEla 2011).

W latach 2015-2019 na terenie badań realizowany był przez Regionalną Dyrekcję Ochrony Środowiska w Lublinie projekt: „W zgodzie z natura - LIFE+ dla Lasów Janowskich". W jego ramach zaplanowane było m.in. prowadzenie ochrony czynnej Pulsatilla patens, mającej na celu poprawę warunków siedliskowych na jej stanowiskach. Przeprowadzone zabiegi ochronne obejmowały usuwanie konkurencyjnych gatunków roślin oraz odsłanianie podłoża, w efekcie miały one sprzyjać przeżyciu i wchodzeniu w stan kwitnienia występujących tam osobników, jak również kiełkowaniu nasion i rekrutacji siewek.

\section{METODYKA}

Badania przeprowadzono w latach 2010-2019 na poligonach wojskowych w Lipie i Nowej Dębie. W pierwszym etapie badań zebrano i zweryfikowano w terenie dostępne (niepublikowane) informacje o występowaniu sasanek na badanych poligonach. W następnych latach zliczano osobniki sasanki otwartej na zinwentaryzowanych wcześniej stanowiskach oraz przeszukiwano systematycznie poligony pod kątem nowych stanowisk obu gatunków sasanek. Na stanowiskach, na których stwierdzono zanik sasanki otwartej, poszukiwania powtarzano w następnych latach. Zmiany w wielkości populacji Pulsatilla patens określono na podstawie siedmiu stanowisk znanych od 2010 r. i corocznie monitorowanych. Jedynie w 2012 r. ze względów logistycznych nie udało się pozyskać kompletu danych. W przypadku $P$. pratensis, dla której nie dokonywano regularnych obserwacji każdego roku, porównano jedynie dane z 2014 i 2019 r.

Jednostką zliczeniową była kępa (osobnik), przyjęto iż jest to zbiór rozet oddalonych od siebie nie więcej niż $10 \mathrm{~cm}$ (KALLIOVIRTA i in. 2006). Liczenia, oprócz ogólnej liczby osobników, obejmowały udział kęp generatywnych oraz liczbę pędów kwiatowych. Szczególną uwagę zwrócono ponadto na pojawianie się siewek oraz osobników juwenilnych. Obserwacji dokonywano w dwóch terminach: pierwszy na przełomie kwietnia i maja, drugi w okresie od końca maja do końca czerwca. Sporadycznie stanowiska były odwiedzane również w miesiącach późniejszych. W trakcie liczenia osobników dokonywano obserwacji uszkodzeń mechanicznych, stanów chorobowych roślin oraz zaburzeń i zmian w siedlisku. Na każdym stanowisku wykonano opis siedliska, zdjęcie fitosocjologiczne metodą Braun-Blanqueta oraz dokumentację fotograficzną. Położenie miejsc występowania określono za pomocą odbiornika GPS, a przestrzenne rozmieszczenie osobników zobrazowano na rycinach.

Na potrzeby zabezpieczenia lokalnej populacji sasanki otwartej, w latach 2015, 2017 i 2019, na poligonie w Lipie zebrano jej nasiona i przesłano do Banku Nasion Polskiej Akademii Nauk Ogród Botaniczny - Centrum Zachowania Różnorodności Biologicznej w Powsinie.

\section{WYNIKI}

\section{Struktura przestrzenna i liczebność populacji}

Osobniki Pulsatilla patens i P. pratensis na badanych poligonach odnajdywano na rozproszonych stanowiskach, które dzielił dystans od kilkuset metrów do kilku kilometrów. W obrębie stanowisk obserwowano pojedyncze kępy lub populacje liczące kilka do 
kilkunastu kęp tworzących skupienia I rzędu, tzn. grupy osobników pozostające w bliskim kontakcie (nie więcej niż 1-2 m). Skupienia I rzędu na tym samym stanowisku często znajdowały się w nieco odmiennych warunkach siedliskowych. W całym okresie badań na poligonie w Lipie stwierdzono dziewięć stanowisk $P$. patens i dwa stanowiska $P$. pratensis, natomiast na poligonie w Nowej Dębie jedno stanowisko P. patens i trzy stanowiska $P$. pratensis. W pięciu przypadkach stanowiska obejmowały dwa skupienia (Ryc. 2).

Całkowita liczebność metapopulacji, uwzględniająca maksymalne wartości na wszystkich stanowiskach z okresu badań, to 36 osobników Pulsatilla patens (Lipa - 34, Nowa Dęba - 2) oraz 34 osobniki P. pratensis (Lipa - 9, Nowa Dęba - 25). Średnia liczba kęp na stanowisku to odpowiednio 3,6 dla sasanki otwartej i 6,8 dla sasanki łąkowej. Najliczniejsze
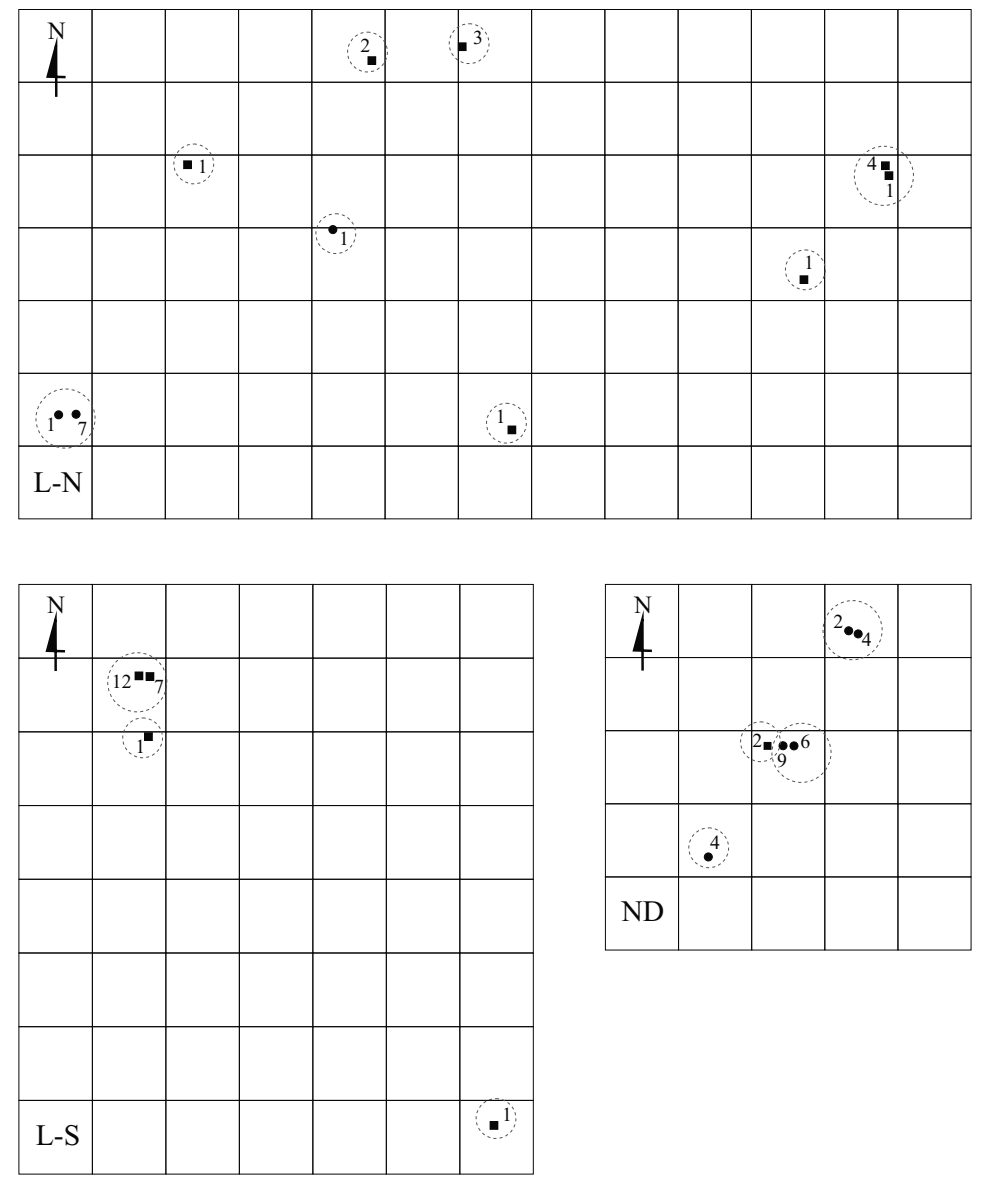

Ryc. 2. Rozmieszczenie Pulsatilla patens (kwadraty) i P. pratensis (koła) na badanych poligonach w siatce kwadratów o boku $250 \mathrm{~m}$. Punkty oznaczają pojedyncze osobniki (kępy) lub ich skupienia z podaniem maksymalnej liczebności w okresie badań, okręgi rysowane przerywaną linią wyznaczają granice stanowisk. L-N - Lipa część północna, L-S Lipa część południowa, ND - Nowa Dęba

Fig. 2. Distribution of Pulsatilla patens (square dots) and Pulsatilla pratesis (round dots) on a grid of $250 \times 250 \mathrm{~m}$ squares. Dots are single clumps or conglomerations of clumps; numbers are the maximum number of individuals found during the study. Circles mark the stands. L-N - northern part of Lipa MTA, L-S - southern part of Lipa MTA, ND - Nowa Dęba MTA 
stanowiska sasanki otwartej i łąkowej liczyły kolejno 19 i 15 kęp. W populacjach obu gatunków występowały zarówno osobniki wegetatywne, jak i generatywne, a udział kęp kwitnących w poszczególnych latach mieścił się w zakresie 0,19-0,56 dla sasanki otwartej oraz 0,44-0,52 dla sasanki łąkowej.

Pojedyncze wegetatywne osobniki sasanek są trudne do odnalezienia na rozległych powierzchniach poligonów, dlatego należy zakładać, że wykazana liczebność może się różnić od rzeczywistej. Jednak biorąc pod uwagę wieloletnie badania, obejmujące wszystkie części poligonów, można z całą pewnością stwierdzić, że zarówno Pulsatilla patens, jak i $P$. pratensis na rozważanym terenie należą do gatunków skrajnie nielicznych.

\section{Zmiany liczebności}

Na poligonie w Lipie, w okresie badań, stwierdzono zanik sasanki otwartej na czterech stanowiskach. W większości pozostałych stanowisk odnotowano spadki liczebności, w jednym przypadku łączyło się to z zanikiem skupienia. Populacja na tym poligonie zmniejszyła się w sumie o 16 osobników. Szczątkowa populacja tego gatunku w Nowej Dębie w latach 2011-2018 liczyła dwa osobniki, a w 2019 r. zmniejszyła się do jednego; ostatni raz kwitnienie obserwowano w 2014 r.

W oparciu o szczegółowy monitoring tego gatunku na siedmiu stanowiskach w Lipie, daje się zauważyć stopniowy spadek liczebności populacji (Ryc. 3). Ogólna liczba kęp na tych stanowiskach zmniejszyła się prawie o połowę, z 32 w 2010 do 17 w 2019 r. W tym samym czasie wysiłki podejmowane przez rośliny w celu reprodukcji miały wyraźnie charakter fluktuacyjny. Udział osobników generatywnych, pomimo ogólnego zmniejszania się populacji, wzrasta od 2015 r. Podobnie średnia liczba kwiatów przypadająca na kępę generatywną, po wyraźnym spadku, powróciła do stanu wyjściowego w 2018, a w 2019 r. wyraźnie go przewyższyła (Ryc. 4).

Porównanie sumarycznej liczebności populacji sasanki łąkowej na całym terenie badań w latach 2014 i 2019 wskazuje na bardziej stabilny stan w porównaniu z gatunkiem

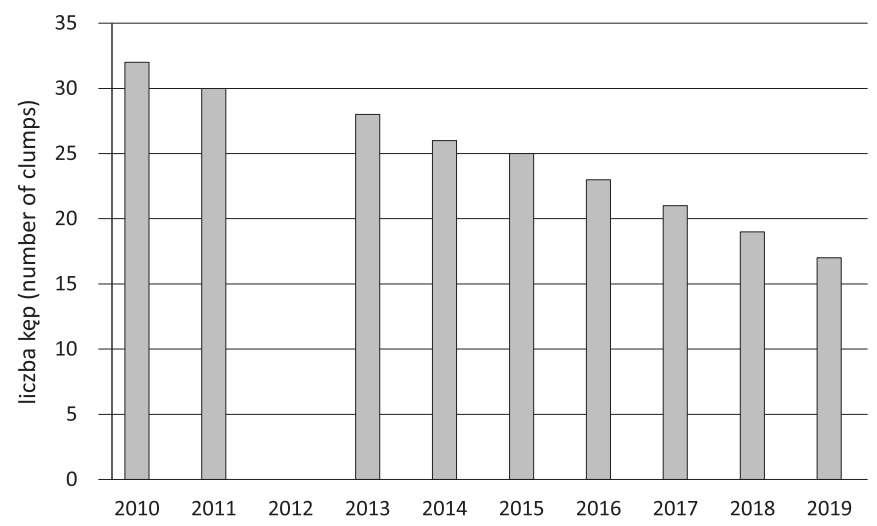

Ryc. 3. Dynamika liczebności populacji Pulsatilla patens na siedmiu stanowiskach na poligonie w Lipie monitorowanych od 2010 r.

Fig. 3. Population dynamics of Pulsatilla patens at seven sites monitored from 2010 onward in the Lipa MTA 


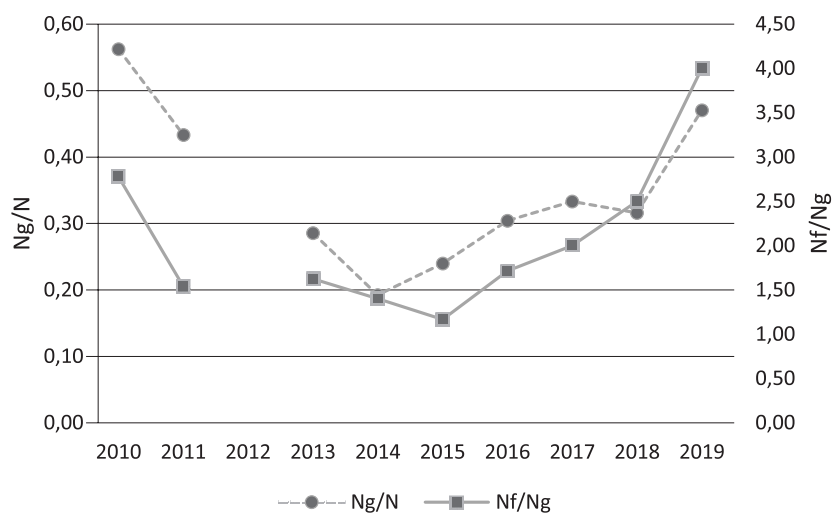

Ryc. 4. Zmiany udziału osobników generatywnych $\left(\mathrm{N}_{\mathrm{g}} / \mathrm{N}\right)$ oraz średniej liczby kwiatów na kępę generatywną $\left(\mathrm{N}_{\mathrm{f}} / \mathrm{N}_{\mathrm{g}}\right)$ u Pulsatilla patens na siedmiu stanowiskach na poligonie w Lipie monitorowanych od 2010 roku. N - liczba wszystkich osobników, $\mathrm{N}_{\mathrm{g}}$ - liczba osobników generatywnych, $\mathrm{N}_{\mathrm{f}}$ - liczba pędów kwiatowych

Fig. 4. Changes in the share of generative clumps $\left(\mathrm{N}_{\mathrm{g}} / \mathrm{N}\right)$ and average number of flowers per generative clump $\left(\mathrm{N}_{\mathrm{f}} / \mathrm{N}_{\mathrm{g}}\right)$ in Pulsatilla patens populations at seven sites monitored from 2010 onward in the Lipa MTA. N - total number of clumps, $\mathrm{N}_{\mathrm{g}}$ - number of generative clumps, $\mathrm{N}_{\mathrm{f}}$ - number of flowering shoots

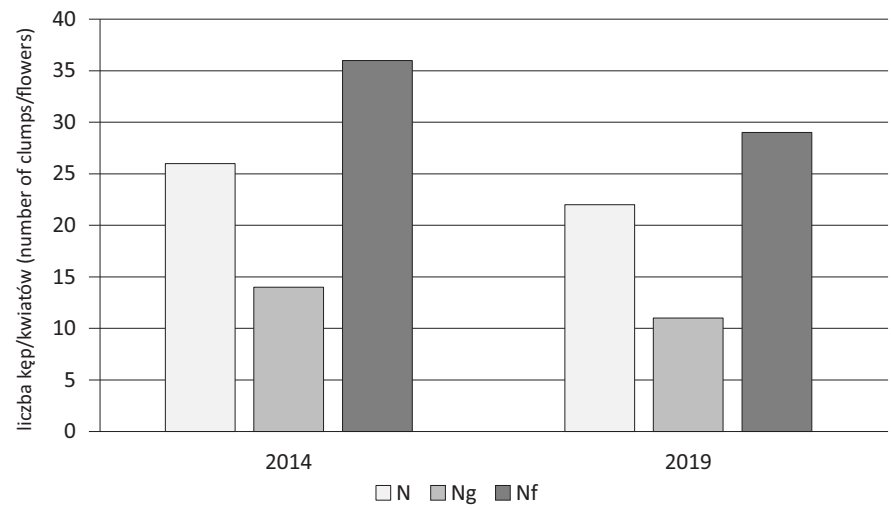

Ryc. 5. Porównanie liczebności osobników Pulsatilla pratensis w metapopulacjach na wszystkich badanych stanowiskach w roku 2014 i 2019. N - liczba wszystkich osobników, $\mathrm{N}_{\mathrm{g}}$ - liczba osobników generatywnych, $\mathrm{N}_{\mathrm{f}}$ - liczba pędów kwiatowych

Fig. 5. Comparison of the number of Pulsatilla pratensis plants in the metapopulations at all surveyed sites in 2014 and 2019. $\mathrm{N}$ - total number of clumps, $\mathrm{N}_{\mathrm{g}}$ - number of generative clumps, $\mathrm{N}_{\mathrm{f}}-$ number of flowering shoots

poprzednim. Odnotowano zanik jednego stanowiska i nieznaczny spadek liczebności (Ryc. 5). Jednak w przypadku populacji w Lipie spadek można uznać za drastyczny, ponieważ zanik jednego stanowiska spowodował redukcję populacji do jednego osobnika.

\section{Preferencje siedliskowe i zbiorowiska roślinne}

Sasanka otwarta i sasanka łąkowa zajmowały bardzo podobne siedliska, a na jednym ze stanowisk rosły obok siebie. Notowane były w różnych zbiorowiskach w obrębie dynamicznego kręgu borów sosnowych - murawy i luźne wrzosowiska, układy ekotonowe (skraje lasów), inicjalne stadia zbiorowisk leśnych. Tylko w jednym przypadku było to dojrzałe 
zbiorowisko boru świeżego. Sasanki wydają się preferować siedliska o częściowym, często nieznacznym ocienieniu; takie stanowiska są liczniejsze i bardziej trwałe. Najliczniejsze skupienie osobników znajduje się w brzeżnych partiach młodego sosnowego lasku. Występowanie obu gatunków związane było zarówno z terenem płaskim, jak i wyniesieniami wydmowymi o różnym nachyleniu i ekspozycji. Stanowiska sasanek często położone były w pobliżu gruntowych dróg, którymi pocięte są poligony.

Fitocenotyczne spektrum sasanek obejmowało murawy napiaskowe (Corynephorion, Koelerion glaucae), wrzosowiska (Pohlio-Callunion, Calluno-Arctostaphylion) oraz bory sosnowe Dicrano-Pinion (Tab. 1). W warstwie zielnej najczęściej występowały: Calluna vulgaris, Carex ericetorum, Corynephorus canescens, Festuca ovina, Peucedanum oreoselinum i Hieracium pilosella, w warstwie mszysto-porostowej - Polytrichum piliferum, Brachytheciaceae spp. oraz Cladonia spp. Pokrycie w warstwie C to średnio ok. 50\%, w warstwie D ok. 30\% (Tab.1).

\section{Zniszczenia, uszkodzenia i stany chorobowe}

W całym okresie badań nie zaobserwowano u sasanek wyraźnych zmian chorobowych, natomiast stosunkowo częstym zjawiskiem były mechaniczne uszkodzenia. Najbardziej prawdopodobną przyczyną uszkodzeń było zgryzanie liści i pędów kwiatowych (najprawdopodobniej przez jeleniowate). Względne straty w całych badanych populacjach, liczone jako proporcja pędów zniszczonych do wszystkich pędów kwiatowych w okresie przed dojrzeniem owoców, spowodowane tego typu zjawiskami mieściły się w zakresie od 0 do 0,43 w poszczególnych latach. Problem ten był obserwowany u obu gatunków.

Zjawiskami, o charakterze losowych zaburzeń siedliska, które mogły mieć wpływ na rośliny, były mechaniczne naruszenia pokrywy glebowej oraz pożary. Były to zjawiska sporadyczne, dotyczyły jednego stanowiska Pulsatilla patens i jednego stanowiska $P$. pratensis. Jedno ze stanowisk sasanki otwartej przetrwało dwa zaburzenia w odstępie trzech lat - naruszenia podłoża (prawdopodobnie buchtowanie dzików) w 2012 i pożar w kwietniu 2015 r. Zdarzenia te nie miały bezpośredniego wpływu na liczebność, zaobserwowano natomiast wzrost liczby pędów kwiatowych w kolejnych latach po pożarze. Bez większych strat wiosenny pożar przetrwała również duża kępa sasanki łąkowej.

Straty związane z bezpośrednią ingerencją człowieka były niewielkie. Na początku maja 2017 r. stwierdzono wykopanie jednego osobnika Pulsatilla patens na poligonie w Lipie. Kontrola wykonana w czerwcu 2017 r. wykazała występowanie kilku małych rozetek rośliny na dnie dołka powstałego po wykopywaniu rośliny. Występowanie tego osobnika potwierdzono również w następnych latach. W przypadku P. pratensis, w 2018 r. w Lipie odnotowano całkowite zniszczenie jednego stanowiska z kilkoma osobnikami w trakcie odnawiania i poszerzania pasa przeciwpożarowego. Była to relatywnie duża strata w odniesieniu do zasobów tego gatunku w Lipie. Sporadycznie obserwowano osobniki sasanki łąkowej zniszczone w wyniku rozjechania lub rozdeptania na jednym ze stanowisk w Nowej Dębie.

Obserwacje owocujących okazów Pulsatilla patens wykazały nieprawidłowy sposób wykształcania się niełupek. Podczas zbioru wykonanego w 2015 r. stwierdzono małe rozmiary niełupek, sugerujące ich niedorozwój, natomiast w 2017 r. stwierdzono nasiona bez 
Tabela 1. Zbiorowiska roślinne z udziałem Pulsatilla patens i P. pratensis

Table 1. Plant communities with Pulsatilla patens and $P$. pratensis

\begin{tabular}{|c|c|c|c|c|c|c|c|c|c|c|c|c|c|}
\hline Nr zdjęcia (No of relevé) & 1 & 2 & 3 & 4 & 5 & 6 & 7 & 8 & 9 & 10 & 11 & 12 & 13 \\
\hline Localizacja (Location) & $\mathrm{L}$ & $\mathrm{L}$ & $\mathrm{L}$ & $\mathrm{L}$ & $\mathrm{L}$ & ND & $\mathrm{L}$ & ND & ND & $\mathrm{L}$ & $\mathrm{L}$ & ND & ND \\
\hline Data (Date) & $\begin{array}{l}\hat{n} \\
\stackrel{8}{ } \\
\ddot{n}\end{array}$ & $\begin{array}{l}\overrightarrow{0} \\
\ddot{0} \\
\dot{ \pm}\end{array}$ & 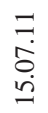 & $\begin{array}{l}\overrightarrow{0} \\
\dot{b} \\
\dot{\Xi}\end{array}$ & 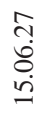 & $\begin{array}{l}\stackrel{0}{\stackrel{5}{0}} \\
\stackrel{0}{\exists}\end{array}$ & $\begin{array}{l}\overrightarrow{0} \\
\ddot{0} \\
\dot{d}\end{array}$ & $\begin{array}{l}n \\
\ddot{n} \\
\ddot{0} \\
\dot{0}\end{array}$ & $\begin{array}{l}\hat{0} \\
\dot{0} \\
\ddot{n}\end{array}$ & $\begin{array}{l}\overrightarrow{0} \\
\ddot{b} \\
\dot{d}\end{array}$ & $\begin{array}{l}\overrightarrow{0} \\
\ddot{b} \\
\dot{\Xi}\end{array}$ & 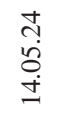 & $\begin{array}{l}\stackrel{+}{\sim} \\
\ddot{\sigma} \\
\dot{\Xi}\end{array}$ \\
\hline Powierzchnia (Area) $\left[\mathrm{m}^{2}\right]$ & 4 & 16 & 16 & 10 & 25 & 25 & 5 & 6 & 16 & 5 & 8 & 6 & 16 \\
\hline Ekspozycja (Exposition) & - & - & - & - & - & $\mathrm{E}$ & - & - & SE & - & - & SW & $\mathrm{S}$ \\
\hline Nachylenie (Inclination) & 0 & 0 & 0 & 0 & 0 & 30 & 0 & 0 & 20 & 0 & 0 & 10 & 20 \\
\hline Pokrycie warstwy (Cover of layer) [\%] & 0 & 0 & 0 & 0 & 25 & 30 & 0 & 0 & 0 & 0 & 0 & 10 & 30 \\
\hline $\mathrm{b}$ & 0 & 0 & 0 & 5 & 20 & 10 & 0 & 0 & 0 & 5 & 20 & 10 & 20 \\
\hline $\mathrm{c}$ & 30 & 50 & 60 & 70 & 40 & 60 & 40 & 50 & 40 & 50 & 40 & 60 & 50 \\
\hline $\mathrm{d}$ & 30 & 40 & 10 & 60 & 50 & 20 & 5 & 30 & 10 & 30 & 30 & 10 & 30 \\
\hline Pulsatilla patens & + & + & + & + & 1 & + & . & . & . & . & . & . & . \\
\hline Pulsatilla pratensis & . & . & . & . & . & . & + & + & + & + & + & 1 & 1 \\
\hline \multicolumn{14}{|l|}{ Ch. Nardo-Callunetea } \\
\hline Calluna vulgaris & 2 & 3 & 3 & 4 & 3 & + & + & . & 1 & 3 & 3 & 1 & 1 \\
\hline Carex ericetorum & 1 & + & 1 & . & . & 1 & + & 1 & 1 & 1 & 1 & + & . \\
\hline Festuca ovina & . & 2 & 1 & 2 & + & 1 & . & . & 2 & 1 & 1 & + & 1 \\
\hline Hieracium pilosella & . & + & + & + & . & . & 1 & 1 & 1 & 1 & 1 & 2 & 1 \\
\hline Pohlia nutans & 1 & + & 1 & 1 & + & 1 & . & . & . & + & + & . & . \\
\hline Cladonia chlorophaea s.lato & 1 & + & 1 & + & + & . & . & . & + & . & + & . & . \\
\hline Hieracium umbellatum & . & + & + & . & . & + & . & . & + & . & . & . & + \\
\hline Luzula campestris & . & . & . & . & . & + & . & . & + & + & . & + & + \\
\hline Cladonia deformis & + & + & + & + & . & . & . & . & . & . & . & . & . \\
\hline \multicolumn{14}{|c|}{ Ch. Koelerio glaucae-Corynephoretea canescentis } \\
\hline Polytrichum piliferum & 3 & 3 & 1 & 2 & . & + & 1 & + & 2 & 2 & 2 & 1 & . \\
\hline Rumex acetosella & + & + & + & + & . & 1 & + & . & 1 & + & + & + & + \\
\hline Spergula morisonii & + & 1 & . & + & . & . & + & + & + & 1 & + & + & . \\
\hline Corynephorus canescens & 2 & 1 & 2 & + & . & . & 2 & 1 & 1 & . & 1 & . & . \\
\hline Brachythecium albicans & . & . & + & 2 & . & . & . & 1 & + & 1 & + & + & 1 \\
\hline Cladonia subulata & 1 & 1 & + & 1 & . & . & + & . & + & 1 & + & . & . \\
\hline Ceratodon purpureus & . & 1 & + & . & + & . & . & + & 1 & 1 & + & . & . \\
\hline Thymus serpyllum & . & . & 1 & . & . & . & . & 2 & 1 & + & . & 2 & + \\
\hline Cladonia macilenta subsp. floerkeana & + & + & + & 1 & . & . & . & + & . & . & + & . & . \\
\hline Agrostis vinealis & + & . & 2 & + & + & . & + & . & + & . & . & . & . \\
\hline Jasione montana & . & + & + & . & . & . & + & + & + & . & . & . & . \\
\hline Scleranthus perennis & . & . & . & . & . & . & . & + & + & + & + & + & . \\
\hline Cladonia arbuscula subsp. mitis & 1 & . & + & + & . & . & . & 1 & . & . & . & + & . \\
\hline Koeleria glauca & . & . & + & . & . & . & . & 2 & + & . & r. & + & . \\
\hline Veronica dillenii & . & . & . & . & . & . & + & 1 & . & . & . & + & . \\
\hline \multicolumn{14}{|l|}{ Ch. Trifolio-Geranietea sanguinei } \\
\hline Peucedanum oreoselinum & . & + & + & + & + & 1 & + & + & 1 & + & + & 1 & 1 \\
\hline Polygonatum odoratum & . & + & 1 & . & . & 1 & . & + & + & . & . & + & 1 \\
\hline
\end{tabular}


Tabela 1. Kontynuacja - Table 1. Continued

\begin{tabular}{|c|c|c|c|c|c|c|c|c|c|c|c|c|c|}
\hline Nr zdjęcia (No of relevé) & 1 & 2 & 3 & 4 & 5 & 6 & 7 & 8 & 9 & 10 & 11 & 12 & 13 \\
\hline Silene nutans & . & . & . & . & . & + & . & . & . & . & . & + & + \\
\hline Geranium sanguineum & . & . & . & . & . & . & . & . & + & . & . & + & + \\
\hline \multicolumn{14}{|l|}{ Ch. Vaccinio-Piceetea } \\
\hline Pinus sylvestris a & . & . & . & . & 2 & 3 & . & . & . & . & . & 2 & 3 \\
\hline Pinus sylvestris b & . & . & . & . & . & 2 & . & . & . & 1 & 2 & 2 & 2 \\
\hline Pinus sylvestris c & . & . & . & + & . & + & . & . & . & . & . & . & . \\
\hline Pleurozium schreberii & . & . & + & 1 & 2 & 2 & . & . & . & + & . & . & 1 \\
\hline Cladonia furcata & . & . & + & + & + & + & . & . & . & . & . & + & . \\
\hline Dicranum polysetum & . & . & + & + & 2 & . & . & . & . & . & . & . & + \\
\hline Dicranum scoparium & . & . & + & + & + & + & . & . & . & . & . & . & . \\
\hline Cladonia gracilis & + & . & . & + & + & . & . & . & . & . & . & . & . \\
\hline \multicolumn{14}{|l|}{ Inne (Others) } \\
\hline Cladonia macilenta subsp. macilenta & 1 & + & + & + & + & . & + & . & + & + & 1 & . & . \\
\hline Solidago virgaurea & . & + & + & . & + & + & . & . & + & . & + & . & + \\
\hline Viscaria vulgaris & . & + & + & . & . & + & + & . & 1 & . & . & + & + \\
\hline Brachythecium sp. & . & . & + & 2 & 1 & 2 & . & 1 & . & . & . & 2 & 2 \\
\hline Cladonia phyllophora & 2 & 1 & 1 & 2 & . & . & + & + & + & + & . & . & . \\
\hline Lembotropis nigricans & + & . & + & . & + & . & . & . & + & . & . & + & + \\
\hline Vincetoxicum hirundinaria & . & . & . & . & + & + & . & + & 1 & . & . & + & + \\
\hline Calamagrostis epigejos & . & 2 & 1 & . & . & . & 2 & + & . & + & . & . & . \\
\hline Euphorbia cyparissias & . & . & . & . & . & + & . & + & + & . & . & + & + \\
\hline Cladonia rei & . & + & + & + & . & . & . & + & . & + & + & . & . \\
\hline Cladonia sp. & . & + & . & + & . & + & + & . & . & . & . & + & . \\
\hline Hypnum cupressiforme & . & . & + & + & + & . & . & . & . & 1 & + & . & . \\
\hline Sciuro-hypnum oedipodium & . & . & 1 & 1 & 1 & . & . & . & . & + & . & + & . \\
\hline Quercus robur c & . & . & . & . & + & + & . & . & . & . & . & + & + \\
\hline Convallaria majalis & . & 2 & . & . & . & 2 & . & . & 2 & . & . & . & 2 \\
\hline Hypericum perforatum & . & . & . & . & . & . & + & . & + & . & . & + & + \\
\hline Cladonia fimbriata & . & . & . & . & + & . & + & . & . & + & + & . & . \\
\hline Quercus robur b & . & . & . & . & 2 & . & . & . & . & 1 & 1 & . & . \\
\hline Calamagrostis arundinacea & . & . & . & . & . & 1 & . & . & . & . & . & + & + \\
\hline Dianthus carthusianorum & . & . & . & . & . & + & . & + & . & . & . & + & . \\
\hline Chamaecytisus ratisbonensis & . & + & . & . & . & . & + & . & . & . & + & . & . \\
\hline Potentilla arenaria & . & . & . & . & + & . & . & 2 & . & . & . & + & . \\
\hline Pteridium aquilinum & . & . & . & . & . & 2 & . & . & . & . & . & + & 2 \\
\hline Cephaloziella divaricata & . & . & + & + & . & . & . & + & . & + & . & . & . \\
\hline Trapeliopsis granulosa & . & + & . & + & . & . & . & . & . & . & + & . & . \\
\hline \multicolumn{14}{|c|}{ 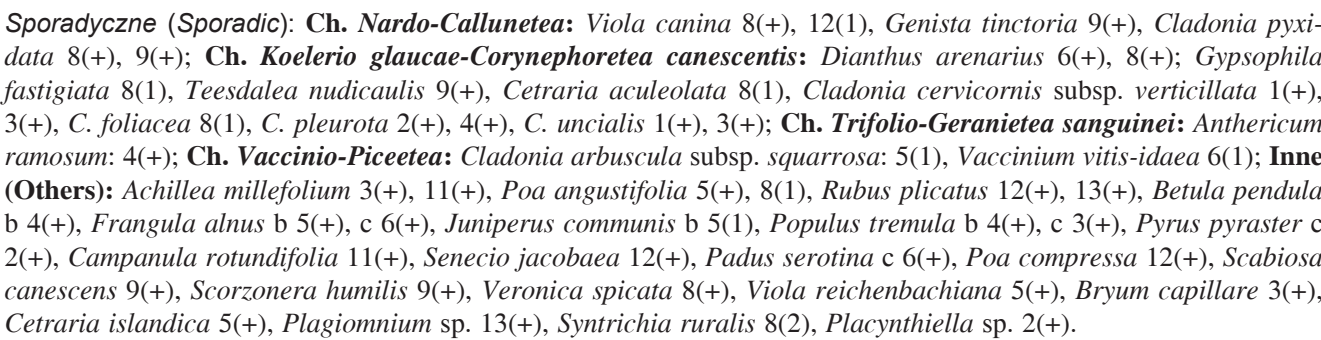 } \\
\hline
\end{tabular}


prawidłowo wykształconej niełupki. Według informacji pracowników Ogrodu Botanicznego w Powsinie nasiona były pozbawione zdolności kiełkowania, nie zawierały zarodków lub zawierały zarodki zdegenerowane (A. Kapler inf. ustna). Prawidłowo wykształcone niełupki zaobserwowano dopiero w 2019 r., co zbiegło się w czasie z obfitym kwitnieniem roślin. Problemów z prawidłowym wykształcaniem nasion nie odnotowano w przypadku drugiego gatunku sasanki. W trakcie całego okresu badań nie stwierdzono obecności siewek ani typowych osobników juwenilnych sasanki otwartej. Nieznaczne odnawianie się populacji zauważono natomiast w przypadku sasanki łąkowej w Nowej Dębie.

Faktem wartym odnotowania jest odnalezienie na jednym ze stanowisk sasanki łąkowej w Nowej Dębie wegetatywnego osobnika o cechach pośrednich pomiędzy Pulsatilla patens i $P$. pratensis, prawdopodobnie mieszańca obu gatunków.

\section{DYSKUSJA}

Przeprowadzone badania wskazują, że sasanki należą do roślin skrajnie nielicznych w regionie, a ich metapopulacje składają się z niewielkich skupień lub pojedynczych osobników występujących w dużym rozproszeniu. Według modelowych wzorców, przestrzenne rozmieszczenie osobników sasanek przyjmuje strukturę rozproszono-kępową (FALIŃSKI 1990) lub pojedynczo-kępową (JACKOWIAK 1998), która jest charakterystyczna dla gatunków w fazie daleko posuniętej recesji.

Na regularnie monitorowanych stanowiskach populacja Pulsatilla patens zmniejszyła się w ciągu dekady niemal o połowę. Spadek liczebności na badanym terenie w dłuższej perspektywie czasowej potwierdzają też relacje starszych pracowników Lasów Państwowych i przyrodników (L. Kaczmarzyk inf. ustna; K. Pałka inf. ustna). Szybki zanik w południowo-wschodniej Polsce jest zbieżny z obserwacjami w innych częściach kraju i państwach ościennych. Dla przykładu w rezerwatach północno-wschodniej Polski w latach 1955-2010 odnotowano zanik 60\% stanowisk P. patens (JuśKIEWICZ-SwACZYNA 2010). Na obfitym stanowisku w Niemczech oszacowano, że populacja tego gatunku w okresie 12 lat zmniejszyła się o 2/3 (RöDER \& KIEHL 2006). Na jednym ze stanowisk na Górnym Śląsku odnotowano zanik populacji liczącej kilkaset rozet w zaledwie pięć lat (CHMURA 2001).

Pomimo że w Europie w obecnym stuleciu, odnajdywano jeszcze populacje Pulsatilla patens o liczebności rzędu 10 tys. osobników (PILT \& KUKK 2002; RöDER \& KIEHL 2006), to najczęściej na stanowiskach gatunku, szczególnie na skraju zasięgu, stwierdzane są bardzo małe populacje liczące do 10 osobników (KALliovirTa i in. 2006; PAWLiKowsKi 2012; Czerepko i in. 2014). Podobną sytuację obserwuje się w przypadku P. vernalis w Polsce, który w części niżowej uważany jest za relikt klimatyczny (GRZYL \& RoNIKIER 2011). Sasanka łąkowa jest obecnie najmniej zagrożonym przedstawicielem rodzaju w kraju, jednak ostatnie prace sugerują, że i ten gatunek jest w wyraźnej recesji, a opisywane stanowiska są najczęściej nieliczne (KRZEPTOwsKa i in. 2006; GRZYL 2012; KAPLER i in. 2015; OKLEJEWICZ $\mathrm{i}$ in. 2015).

Wymieranie sasanek, w szczególności sasanki otwartej, w II połowie XX w. oraz w obecnym stuleciu łączone jest przede wszystkim z przemianami w obrębie zbiorowisk borowych, które są wynikiem zmian w użytkowaniu lasów (skuteczna ochrona przeciwpożarowa, zanik 
wypasu i grabienia ściółki, przebudowa drzewostanów). W rezultacie powoduje to wzrost grubości ściółki, pokrycia runa oraz zacienienia dna lasu (SZCZYGIELSKI 2007; ZYCH 2007; CZEREPKO $i$ in. 2014; ZAŁUSKI $i$ in. 2015). Zanikaniu ulegają też siedliska nieleśne, jak murawy i wrzosowiska, które są miejscem występowania tych gatunków. Reakcją na te zmiany jest wycofywanie się wielu gatunków, w tym sasanek, w siedliska marginalne, jak leśne przydroża, zbocza nasypów lub skraje lasów (GRZYL \& RONIKIER 2011; ZiELIŃsKA i in. 2016). Podobnie, rolę refugiów pełnią współcześnie tereny poligonów wojskowych.

Sasanki występują w szerokim zakresie warunków świetlnych, preferują jednak miejsca otwarte i półotwarte (Uotila 1996; Pilt \& KuKK 2002; KALlioviRTA i in. 2009; JuśKIEWICZSWACZYNA \& GRZYBOWSKI 2013). W przypadku sasanki otwartej, uważa się obecnie, że czynnikiem limitującym jest nie tyle światło, co stadium sukcesyjne zbiorowiska. Sasanka otwarta jest co prawda rośliną długowieczną, ale słabo konkurencyjną, a dodatkowo nie buduje trwałego banku nasion. Taka strategia życiowa jest skuteczna w warunkach powtarzających się zaburzeń, a regenerujące się płaty roślinności stanowią optymalne siedliska dla gatunku. Długotrwała stabilność siedliska powoduje stopniową eliminację wskutek ekspansji gatunków silnie konkurencyjnych, jak wrzosowate czy trawy. Istotną rolę w takich pośrednich stadiach sukcesji odgrywają luki w roślinności i w warstwie ściółki, umożliwiające kiełkowanie nasion i rekrutację nowego pokolenia (KALAMEES 2005; RÖDER \& KIEHL 2006; JuŚKIEWICZ-SwACZYNA \& CHOSZCZ 2012). Uważa się, że dla sasanki otwartej optymalne są pośrednie stadia sukcesji, które dają możliwość do rozwoju nowych osobników, a jednocześnie minimalizują niekorzystne oddziaływania skrajnych zjawisk pogodowych, takich jak susze czy niskie temperatury (RöDER \& KIEHL 2006; KALlioviRTA i in. 2009). W literaturze często podkreśla się rolę pożarów jako czynnika szczególnie istotnego dla zachowania dogodnych siedlisk dla sasanki otwartej (KALAMEES 2005; KALLIOVIRTA i in. 2009). Niektóre badania wskazują, że rozluźnienie pokrywy roślinnej, szczególnie warstwy mszystej oraz ściółki, nie tylko umożliwia kiełkowanie, ale również intensyfikuje kwitnienie (KalliovirTa i in. 2009; JuśKIEwicZ-SwaczYNA \& ChoszCZ 2012). Nie jest zatem wykluczone, że obserwowany wzrost intensywności kwitnienia sasanki otwartej w Lipie w latach 2018-2019 był związany z zabiegami ochrony czynnej tego gatunku.

O ile poza poligonami spadek liczebności sasanek można wiązać z kurczeniem się optymalnych siedlisk, o tyle na czynnych poligonach czynnik ten wydaje się nie mieć większego znaczenia. W przypadku poligonów w Lipie i Nowej Dębie z negatywnymi przemianami roślinności można wiązać jedynie zanik Pulsatilla patens na jednym ze stanowisk, chociaż to potencjalnie niekorzystne zjawisko można obserwować również w innych miejscach. Do konkurencyjnych gatunków, pogarszających właściwy stan siedliska sasanek, zaliczyć można Calluna vulgaris, Calamagrostis epigejos, Convallaria majalis lub Pteridium aquilinum, a także mchy plagiotropowe (Pleurozium schreberii, Sciuro-hypnum oedipodium, Brachythecium sp.). Ogólnie jednak poligony obfitują w potencjalne, optymalne siedliska sasanek - murawy, luźne wrzosowiska, piaszczyste pobocza gruntowych dróg, ekotony czy inicjalne bory, z dużym udziałem luk w pokrywie roślinnej. Co ważne, pożary na czynnych poligonach są czynnikiem stale obecnym i w istotny sposób wpływają na kształtowanie się fitocenoz.

Jedną z bardziej prawdopodobnych przyczyn zanikania sasanek są zmiany klimatyczne. Hipotezę taką może do pewnego stopnia potwierdzać wzorzec kurczenia się zasięgu sasanki 
otwartej w Polsce. Badane na poligonach stanowiska leżą na granicy zasięgu Pulsatilla patens, dlatego należy zakładać że pod wpływem ocieplania klimatu to one jako pierwsze będą zanikać wraz z przesuwającą się w kierunku północno-wschodnim granicą zasięgu. Z obserwacji wynika, że czynniki klimatyczne mają wpływ na rozwój osobników, intensywność kwitnienia i owocowania sasanek. Efektem tego są notowane często fluktuacje w liczbie osobników generatywnych i pędów kwiatowych, a w konsekwencji też liczebności populacji. Przyjmuje się, że na rozwój i reprodukcję sasanki otwartej działają pozytywnie wyrównane temperatury w zimie (bez okresów ociepleń), ciepła i słoneczna wiosna oraz duża ilość opadów latem (WóJTowicz 2000, 2004). Zmiany klimatyczne mogą ponadto wpływać pośrednio na reprodukcję sasanek, powodując zakłócenia w interakcji roślina - zapylacz, np. brak synchronizacji pomiędzy okresem aktywności zapylaczy a kwitnieniem (TORVIK i in. 1998; HeGLAND i in. 2009). W ostatnich latach mocnych dowodów na wpływ czynnika klimatycznego dostarczono w stosunku do krajowej populacji $P$. vernalis. Wykazano, że istnieją dosyć wyraźne korelacje pomiędzy reprodukcją generatywną, a takimi czynnikami, jak temperatura, nasłonecznienie i wielkość opadów w okresach krytycznych (GRZYL i in. 2014). Zależności te są podobne jak w przypadku $P$. patens, a wyciągane wnioski jednoznacznie wskazują na negatywny wpływ zmian klimatycznych na te gatunki, z czego kluczowe znaczenie wydaje się mieć hamowanie kiełkowania nasion powodowane letnimi suszami. Nie jest jasne w jaki sposób zmiany klimatyczne wpłyną na $P$. pratensis, jednak z obserwacji populacji estońskich wynika, że w porównaniu z P. patens, gatunek ten lepiej znosi suche lata (PILT \& KuKK 2002).

Na podstawie obserwacji z badanych poligonów można wyciągnąć wniosek, że bezpośrednią przyczyną zaniku sasanki otwartej są problemy związane z rozmnażaniem, a zwłaszcza z prawidłowym wykształcaniem nasion. Konsekwencją tego jest stopniowe starzenie się i zanikanie populacji. Co istotne, podczas całego okresu badań nie odnotowaliśmy ani jednej pewnej obserwacji, wskazującej na generatywne odnawianie się populacji (brak siewek i osobników juwenilnych). Podobnie w innych częściach zasięgu, w wielu przypadkach w populacjach nie obserwuje się w ogóle siewek i osobników juwenilnych (KALLIOVIRTA i in. 2009; PAwLIKOWSKi 2012).

Bardzo mała ogólna liczebność, niekorzystna struktura przestrzenna oraz izolacja badanych populacji sasanek powoduje, że obecnie istotną przyczyną zanikania mogą być niekorzystne zjawiska na poziomie genetycznym (depresja wsobna, dryf), prowadzące do spadku dostosowania i obniżenia kondycji zdrowotnej roślin. Badania populacji sasanki otwartej w środkowowschodniej Europie wskazują, iż populacje Pulsatilla patens charakteryzują się niską wewnątrzpopulacyjną różnorodnością genetyczną (SZCZECIŃSKA i in. 2016). Nawet w obrębie jednego poligonu, niewielkie skupienia roślin oddalone o kilkaset metrów, mają znikomą szansę na zapylenie krzyżowe. Dodatkowo, małe populacje kwitnących roślin są omijane przez owady, jeśli w pobliżu znajdują się inne obfite źródła pokarmu (TORVIK i in. 1998). Brak zapylenia krzyżowego czy krzyżowanie się blisko spokrewnionych osobników, może w rezultacie prowadzić do braku lub powstawania nieprawidłowo rozwiniętych owoców.

Mała populacja to także mniejsza odporność na zdarzenia losowe (niszczenie, uszkodzenia, choroby), które w pewnym momencie mogą doprowadzić do całkowitego zaniku rośliny na stanowisku. Takim niekorzystnym oddziałaniem na szczątkową populację może 
być większa presja roślinożerców zgryzających pędy generatywne, co odnotowaliśmy na badanym terenie, a potwierdzają to także inni autorzy (UOTILA 1996; ZYCH 2007; JUŚKIEwiCZ-SwaCZYNA \& ChOszCZ 2012).

Podsumowując, zanik sasanek na poligonach wojskowych w południowo-wschodniej Polsce należałoby obecnie łączyć ze zmianami klimatycznymi oraz z erozją genetyczną małych, izolowanych populacji. Czynne poligony, pomimo dogodnych warunków siedliskowych, prawdopodobnie nie będą w stanie zapewnić ciągłości populacji tych gatunków bez dodatkowych zabiegów ochrony czynnej jak np. namnażanie ex situ i zasilanie dzikiej populacji.

Podziękowania. Autorzy składają podziękowania Panu Leszkowi Kaczmarzykowi, Państwu Annie i Tadeuszowi Cieślakom oraz dr. Krzysztofowi Pałce, Markowi Kołodziejczykowi i Dariuszowi Mrozowi za pomoc w zlokalizowaniu stanowisk sasanki otwartej oraz mgr. Adamowi Kaplerowi za informacje o kondycji zdrowotnej przesłanych nasion.

\section{LITERATURA}

Ceynowa M. 1968. Zbiorowiska roślinności kserotermicznej nad dolną Wisłą. - Studia Societatis Scientiarum Torunensis 8(4): 1-155.

Chmura D. 2003. Zagrożenia lokalnych populacji sasanki otwartej Pulsatilla patens na przykładzie stanowiska na Sodowej Górze w Jaworznie. - Chrońmy Przyrodę Ojczystą 59(5): 14-27.

CioseK M. T. 1999. Rodzaj Pulsatilla (Ranunculaceae) na Podlasiu i Mazowszu. - Fragmenta Floristica et Geobotanica Series Polonica 6: 15-19.

Ciosek M. T., PióRek K., Sikorski R. \& Tręiı́cka A. 2016. Population dynamics of Pulsatilla patens (L.) Mill. in a new locality in Poland. - Biodiversity: Research and Conservation 41: 61-68.

Cwener A., Michalczuk W. \& Krawczyk R. 2016. Red list of vascular plants of Lublin Region. - Annales Universitatis M. Curie-Skłodowska, Sectio C. 71(1): 7-26.

CZerepko J., Gawryś R. \& CieŚla A. 2014. Wpływ zagospodarowania lasu na stan zachowania sasanki otwartej Pulsatilla patens (L.) Mill. - Sylwan 158(1): 26-33.

DYREKTYwa 1992. Dyrektywa Rady 92/43/EWG z dnia 21 maja 1992 roku w sprawie ochrony siedlisk przyrodniczych oraz dzikiej fauny i flory.

FALIŃsKi B. 1990. Kartografia geobotaniczna. Cz. 1. Zagadnienia ogólne. Kartografia florystyczna i fitogeograficzna. s. 284. PPWK im. E. Roemera, Warszawa-Wrocław.

GrZYL A. 2012. Pulsatilla pratensis (L.) Mill. sasanka łąkowa. - W: R. OlaCzeK (red.), Czerwona księga roślin województwa łódzkiego. Zagrożone rośliny naczyniowe. Zagrożone zbiorowiska roślinne, s. 164-165. Ogród Botaniczny w Łodzi, Uniwersytet Łódzki, Łódź.

GrZYL A. \& RoniKIER M. 2011. Pulsatilla vernalis (Ranunculaceae) in the Polish Lowlands: current population resources of a declining species. - Polish Botanical Journal 56(2): 185-194.

GrZYl A., KiedrZYŃSKi M., ZieLIŃSKA K. M. \& RewiCZ A. 2014. The relationship between climatic conditions and generative reproduction of a lowland population of Pulsatilla vernalis: the last breath of a relict plant or a fluctuating cycle of regeneration? - Plant Ecology 215: 457-466.

Hegland S. J., Nielsen A., Lázaro A., Bjerknes A. \& Totland Ø. 2009. How does climate warming affect plant-pollinator interactions? - Ecology Letters 12: 184-195.

Hultén E. \& Fries M. 1986. Atlas of North European vascular plants north of the Tropic of Cancer. Köeltz, Konigstein. 
JACKOWIAK B. 1998. Struktura przestrzenna flory dużego miasta. Studium metodyczno-problemowe. - Prace Zakładu Taksonomii Roślin Uniwersytetu A. Mickiewicza w Poznaniu 8: 1-228. Bogucki Wydawnictwo Naukowe, Poznań.

Jalas J. \& SuOminen J. (red.). 1989. Atlas Florae Europaeae. Distribution of vascular plants in Europe 8. Nymphaeaceae to Ranunculaceae. s. 261. Committee for Mapping the flora of Europe, Societas Biologica Fennica, Vanamo, Helsinki.

JuśKIEWICZ-SwaCZYNA B. 2010. Distribution and abundance of Pulsatilla patens populations in nature reserves in north-eastern Poland. - Polish Journal of Natural Sciences 25(4): 376-386.

JuśKIEwICZ-SwaczYNA B. \& CHOszcz D. 2012. Effect of habitat quality on the structure of populations of Pulsatilla patens (L.) Mill. (Ranunculaceae) - rare and endangered species in European flora. - Polish Journal of Ecology 60(3): 567-576.

JuŚKIEwicZ-SwacZYNA B. \& GRZYBowSKI M. 2013. Effect of environmental factors on the structure of populations of Pulsatilla patens (L.) Mill. - Polish Journal of Natural Sciences 28(3): 349-362.

Kalamees R., Püssa K., Vanha-Majamaa I. \& Zobel K. 2005. The effect of fire and stand age on seedling establishment of Pulsatilla patens in a pine-dominated boreal forest. - Canadian Journal of Botany 83: 688-693.

Kalliovirta M., Ryttäri T. \& Heikkinen R. K. 2006. Population structure of a threatened plant, Pulsatilla patens, in boreal forests: modeling relationships to overgrowth and site closure. - Biodiversity and Conservation 15: 3095-3108.

Kapler A., Gawryś W., Szmit B. \& Krzyżewski A. 2015. Nowe liczne stanowisko sasanki łąkowej Pulsatilla pratensis (Ranunculaceae) na Wysoczyźnie Ciechanowskiej. - Chrońmy Przyrodę Ojczystą 71(6): 470-475.

Kaźmierczakowa R., Zarzycki K. \& Mirek Z. (red.). 2014. Polska czerwona księga roślin. Paprotniki i rośliny kwiatowe. s. 895. Wyd. III. Instytut Ochrony Przyrody PAN, Kraków.

Kaźmierczakowa R., Bloch-OrŁowska J., Celka Z., Cwener A., Dajdok Z., Michalska-Hejduk D., PAWlikowski P., SzCZĘ́ŚniaK E. \& ZiarneK K. 2016. Polska czerwona lista paprotników i roślin kwiatowych. s. 44. Instytut Ochrony Przyrody Polskiej Akademii Nauk, Kraków.

KRICSFALUSY V. 2016. Variations in the life cycle of Anemone patens L. (Ranunculaceae) in wild populations of Canada. - Plants-Basel 5(3): 29.

Krzeptowska I., Moszkowicz Ł. \& ZabŁocka D. 2006. Populacja sasanki łąkowej Pulsatilla pratensis (L.) Mill. na Skałach Twardowskiego w Krakowie. - Chrońmy Przyrodę Ojczystą 62(2): 28-40.

Nobis M. \& Nobis A. 2009. Stanowisko sasanki otwartej Pulsatilla patens (L.) Mill. (Ranunculaceae) w Starachowicach (Przedgórze Iłżeckie). - Chrońmy Przyrodę Ojczystą 65(4): 299-302.

OKLeJewicz K., Wolanin M. \& Wolanin M. N. 2015. Zagrożone gatunki roślin. - W: Czerwona księga roślin województwa podkarpackiego, s. 11-179. Stowarzyszenie Pro Carpathia, Rzeszów.

PAWLIKowski P. 2012. Sasanka otwarta Pulsatilla patens (1477). Monitoring gatunków i siedlisk przyrodniczych ze szczególnym uwzględnieniem specjalnych obszarów ochrony siedlisk Natura 2000. Wyniki monitoringu. GIOŚ, Warszawa.

Pawlikowski P. \& Wójtowicz W. 2014. Pulsatilla patens (L.) Mill. Sasanka otwarta. - W: R. Kaźmierczakowa, K. ZarzycKi \& Z. MireK (red.), Polska czerwona księga roślin. Paprotniki i rośliny kwiatowe. Wyd. III, s. 186-188. Instytut Ochrony Przyrody PAN, Kraków.

PILT I. \& KukK Ü. 2002. Pulsatilla patens and Pulsatilla pratensis (Ranunculaceae) in Estonia: distribution and ecology. - Proceedings of the Estonian Academy of Sciences: Biology and Ecology 51(4): 242-256.

Rogata D. \& Marcela A. (red.). 2011. Obszary Natura 2000 na Podkarpaciu. Regionalna Dyrekcja Ochrony Środowiska w Rzeszowie, Rzeszów. 
RoZPORZĄDZENIE 2014. Rozporządzenie Ministra Środowiska z dnia 9 października 2014 roku w sprawie gatunków dziko występujących roślin objętych ochroną (Dz. U. 2014, poz. 1409).

RÖDER D. \& KIEHL K. 2006. Population structure and population dynamics of Pulsatilla patens (L.) Mill. in relations to vegetation characteristics. - Flora 201: 499-507.

Szczecińska M., Sramko G., WoŁosz K. \& Sawicki J. 2016. Genetic diversity and population structure of the rare and endangered plant species Pulsatilla patens (L.) Mill in East Central Europe. - PLoS ONE 11(3): e0151730. doi:10.1371/journal.pone.0151730

SzCZYGIELSKI M. 2007. Zmiany charakterystyki fitosocjologicznej borów świeżych Peucedano-Pinetum w puszczach: Piskiej i Augustowskiej na przestrzeni 50 lat. - Studia i Materiały Centrum Edukacji Przyrodniczo-Leśnej w Rogowie 9(2/3): 153-167.

Torvik S. E., Borgen L. \& Berg R. Y. 1998. Aspects of reproduction in Pulsatilla pratensis in Norway. - Nordic Journal of Botany 18: 385-391.

UотіLA P. 1996. Decline of Anemone patens (Ranunculaceae) in Finland. - Symbolae Botanicae Upsalienses 31: 205-210.

Wóstowicz W. 2000. Biologia, wymagania siedliskowe i możliwości uprawy zachowawczej Pulsatilla patens (L.) Mill. - Biuletyn Ogrodów Botanicznych 9: 45-54.

Wójtowicz W. 2004. Pulsatilla patens (L). Sasanka otwarta. - W: B. SudNiK-WójciKowsKa \& H. WeRBLAN-JAKUBIEC (red.), Poradnik ochrony siedlisk i gatunków Natura 2000 - podręcznik metodyczny. Gatunki roślin. 9, s. 168-171. Ministerstwo Środowiska, Warszawa.

ZAJĄC A. \& ZAJąC M. (red.). 2001. Atlas rozmieszczenia roślin naczyniowych w Polsce. s. xii + 714. Nakładem Pracowni Chorologii Komputerowej Instytutu Botaniki Uniwersytetu Jagiellońskiego, Kraków.

Ząuski T., Paszek I., Gawenda-KempczyŃSKa D. \& ŁaZowy-SzcZePanowsKa I. 2015. Problem zachowania gatunków światłolubnych w kompleksie leśnym Górznieńsko-Lidzbarskiego Parku Krajobrazowego. - Studia i Materiały Centrum Edukacji Przyrodniczo-Leśnej w Rogowie 17(1): 145-156.

ZielińsKa K. M., KiedrZYŃski M., GRZYl A. \& Rewicz A. 2016. Forest roadsides harbour less competitive habitats for a relict mountain plant (Pulsatilla vernalis) in lowlands. - Scientific Reports 6: 31913.

ZYch M. 2007. Sasanka otwarta (Pulsatilla patens (L.) Mill.). Krajowy plan ochrony gatunku. s. 40. Transition Facility, Warszawa.

\section{SUMMARY}

Various species of the genus Pulsatilla Mill. are endangered components of European floras (KAŹMIERCZAKOWA et al. 2014, 2016). Their stands are dispersed and the populations usually are very small (KALLIOVIRTA et al. 2006; PAwLIKOWSKi 2012; CZEREPKo et al. 2014). One of the main reasons for the species decline is habitat loss (ZYCH 2007). Military training areas (MTAs), with their specific type of land use, often become refuges for relict populations. The aim of this study was to determine the population size, spatial structure and long-term dynamics of remnant populations of Pulsatilla patens and P. pratensis, and to identify threats to them at two military training areas (Nowa Dęba, Lipa) in south-eastern Poland (Fig. 1). The study area is located on sandy plains surrounded by forest communities. The training grounds are covered by mosaic-like vegetation composed of dry heaths, sandy grasslands and initial stages of pine forest.

The study was conducted between 2010 and 2019. In the first stage of the research, available data on the occurrence of pasque flowers in the study area was collected and verified in the field. In the following years the plants were counted at previously inventoried sites, and the military training areas were systematically explored in search of new sites of Pulsatilla species. The population dynamics of P. patens were determined based on seven sites monitored annually from 2010 onward.

Pulsatilla patens and P. pratensis in the studied training areas occurred at a few scattered sites, where very small numbers of individual plants were observed (Fig. 2). Pasque flowers inhabited psammophilous 
grassland, dry heath, forest edges and initial pine forest (Tab. 1). The metapopulation of P. patens consisted of 36 individuals (Lipa 34, Nowa Dęba 2) occurring at ten sites. For P. pratensis there were 34 individuals (Lipa 9, Nowa Dęba 25) and five sites. The share of generative clumps in the study period was in the range of $0.19-0.56$ for $P$. patens and $0.44-0.52$ for $P$. pratensis.

During the study we observed a significant decrease in the population size of Pulsatilla patens, including the disappearance of four sites. There was a slight decrease for $P$. pratensis, but in Lipa the destruction of plants at one site resulted in a drastic reduction of the local population. Detailed monitoring of $P$. patens at seven sites in Lipa revealed that the number of clumps decreased by almost half, from 32 in 2010 to 17 in 2019. At the same time, the share of generative individuals and the number of flowering shoots varied widely, reaching maximum at the beginning and end of the 10-year observation period (Fig. 4).

The direct cause of the decline of Pulsatilla patens is disruption of reproduction and population regeneration processes. Neither seedlings nor juvenile plants were found at the study sites. Furthermore, the generative clumps produced mostly abnormal seeds unable to germinate. We attribute this to climate change and to the inbreeding depression that is typical for extremely small, isolated populations. Another factor limiting reproduction is grazing of flowering shoots by wild animals, which can cause over $40 \%$ loss of fruit production. Despite their favorable habitat conditions, active military training areas probably cannot ensure the survival of the pasque flower populations unless additional conservation measures are applied.

Wptynęto: 06.03.2020 r.; przyjęto do druku: 21.12.2020 r. 